\title{
Obituary
}

\section{Prof. J. Goodman}

$\mathbf{J}^{\mathrm{o}}$ OHN GOODMAN, who died on October 28, was born on May 1, 1862, at Royston, Herts, receiving his school education at Gravesend and Cambridge. His engineering training followed the orthodox lines of that period-a long apprenticeship of five and a half years, followed by a spell of two years as an assistant to the chief engineer. During this period, by attendance on evening courses and private study, he acquired such a sound knowledge of the scientific principles upon which engineering is based that he was able in 1885 to win a Whitworth scholarship, and entered University College, London, when the chair of engineering was held by Sir Alexander B. W. Kennedy, and in 1886 he became an assistant to his professor.

A short period of service as chief assistant in the Broadway Testing Works, Westminster, was closed by Goodman's appointment in 1890, at the early age of twenty-eight years, to the chair of civil and mechanical engineering at the Yorkshire College, Leeds (now the University of Leeds), in succession to Prof. Archibald Barr, who had been appointed to the chair of engineering at Glasgow. Goodman held this chair for thirty-two years, and, when he resigned in 1922, was made emeritus professor, and was given special accommodation in the University Engineering Laboratories to enable him to carry on the research work which had always been such an important feature of his university work.

Prof. Goodman was an ideal engineering professor, a fluent, lucid lecturer, able always to maintain the interest of his students, and much beloved by them for his deep interest in the social side of their university careers, and by the special efforts he always made to assist them in securing a start in the practical side of their profession. His output of research work was remarkable in view of the amount of teaching work he undertook; the results of these researches, very largely in the field of lubrication of bearings, on the design of roller bearings, on anti-friction metals, and the stresses in crane hooks, etc., were published in numerous papers in the Transactions of the Institutions of Civil and Mechanical Engineers. The Institution of Civil Engineers, to which he was elected in 1887, becoming a full member in 1900, awarded him a Miller scholarship and a Telford premium; he became a full member of the Institution of Mechanical Engineers in 1890. Apart from these papers dealing entirely with the results of research work, Goodman was the author of a wellknown textbook-"Mechanies applied to Engineering"-which has gone through several editions, and has been recognised as a standard work for the young engineering student.

During the Great War, Goodman was attached to the Royal Air Force with the rank of major, and did valuable work in the field of aircraft construction. He was never married.
Sir Temistocle Zammit, C.M.G.

WE regret to record the death, which occurred on November 2 at the age of seventy-one years, of Sir Temistocle Zammit, formerly rector of the University of Malta.

Temistocle Zammit was born in Malta in 1864 and educated at the local university, where he took the degree of M.D. in 1889. Entering the service of the Government of the island as an analyst, he became a member of the commission appointed by the Colonial Office and the Royal Society to investigate malaria. In 1904 he represented the Government on the Mediterranean Fever Commission, and in the following year became professor of chemistry in his University. To him was due the discovery which led to the recognition of the organisms of Malta fever in the blood of the native goat, and in 1908 he became a member of the Commission appointed to combat this disease. For the remainder of his life, such time as could be spared from his other pre-occupations was given to research in this direction. From 1920 until 1926 he was rector of the University. He was a member of the Council of Government and of the Executive Council of Malta. He received the Mary Kingsley Medal of the Liverpool School of Tropical Medicine in recognition of his services in medical research.

While Zammit's services to medical science were widely recognised among members of his own profession, he was far more widely known as an archæologist, more especially for his contributions to our understanding of the obscure archæological problems in the prehistory of Gozo and his native island. After he had been appointed curator of the Malta Museum in 1903, he discovered and excavated the neolithic temples of Tarxien and Imgiar, and took in hand and completed the excavations already begun in the other subterranean temples of Malta. In 1926, after his retirement from the rectorship of the University, he became director of the enlarged Museum Department, and brought together and arranged a remarkable exhibit of Stone Age antiquities such as is unsurpassed elsewhere. It is entirely owing to his enthusiasm and knowledge that the antiquities of Malta have been made more accessible and more easily intelligible to the visitor to the island, whether archæologist or layman, than in any other European centre of archæological interest. Under his editorship, the official publications of the Department became a valuable source of first-hand information. He was the author of "Malta, the Island and its History" (1926) and "The Neolithic Temples of Tarxien" (1930), indispensable to the student of the early history of the Mediterranean.

The honorary degree of D.Litt. was conferred on Zammit by the University of Oxford in 1920. He was made a C.M.G. in 1911 and knighted in 1930. He was also an honorary fellow of the Royal Anthropological Institute. 